\title{
ТЕОРЕТИЧНІ АСПЕКТИ ЗАСТОСУВАННЯ СТРЕС-ТЕСТУВАННЯ У БАНКІВСЬКІЙ СИСТЕМІ УКРАЇНИ
}

В умовах глобалізачії світової економіки, кількісні та якісні характеристики ризиків зростають, щзо спонукає банки до розробки та впровадження в повсякденну діяльність механізмів які не тільки забезпечують мінімізацію ризиків, а $i$ їх прогнозування, які в кінцевому порядку дадуть можливість на тільки зменшити негативний вплив ризиків на фінансово-господарську діяльність банків, а у самому оптимальному варіанті взагалі запобігти їх виникненню. Одним із таких інструментів, який став популярним та набув своєї актуальності в останні десятиліття, стало стрес-тестування.

Перехід до пруденційних процесів регулювання фінансових секторів економіки, які в останні роки стають пріоритетними, вимагає від наукового середовища виявлення спільних ознак фінансових криз, ідентичності окремих їх прочесів, виявлення та класифікацію реперних точок, вплив на які дасть максимальний ефект від розробки та впровадження антикризових заходів. Крім того набуває актуальності питання розробки та уніфікаиї методів та моделей проведення стрес-тестування.

Важливим моментом для підвищення ефективності процесу стрес-тестування є розуміння його сутності, мети проведення, та завдань, які будуть вирішені в процесі стрес-тестування банків.

Проведене в роботі дослідження дає змогу стверджувати, щуо стрес-тестування - изе процес кількісної оцінки ризику, який полягає у визначенні величини неузгодженої позииії, яка наражає банк на ризик, та у визначенні кількісних показників зовнішніх чинників вплив, які показують, яку суму збитків отримає банк, якщз подї розвиватимуться за закладеними негативними сценаріями, розробці заходів по встановленню кількісних показників діяльності окремого банку чи банківської системи краӥни в цілому, щзо забезпечать створення відповідних умов діяльності, за яких банк чи банківська система в иілому зможе запобігти впливу негативних явищ взагалі, або максимально мінімізувати їх вплив.

Метою проведення стрес-тестування є досягнення окремим банком, чи банківською системою в цілому такого стану, при якому буде забезпечено максимально можливу мінімізацію впливу негативних подій на мікро - та макрорівні, які мають малоймовірний характер, проте можуть призвести до кризових ситуацій.

Ключові слова: ризик-менеджмент, стрес-тестування, банківські ризики, методи стрестестування, мета стрес-тестування.

Ю.М. БЕЗДИТКО

Херсонский национальный технический университет

О.М. ПОСАДНЕВА

Херсонский национальный технический университет

М.В. КАГАРЛИЦКАЯ

Херсонский национальный технический университет

\section{ТЕОРЕТИЧЕСКИЕ АСПЕКТЫ ПРИМЕНЕНИЯ СТРЕСС-ТЕСТИРОВАНИЯ В БАНКОВСКОЙ СИСТЕМЕ УКРАИНЫ}

В условиях глобализачии мировой экономики, количественные и качественные характеристики рисков растут, что побуждает банки к разработке и внедрению в повседневную деятельность механизмов, которые не только обеспечивают минимизацию рисков, а и их прогнозирования, которые в конечном порядке дадут возможность на только уменьшить негативное влияние рисков на финансово хозяйственную деятельность банков, а в самом оптимальном варианте вообще предотвратить их возникновение. Одним из таких инструментов, который стал популярным и приобрел свою актуальность в последние десятилетия, стало стресс-тестирования.

Переход к пруденциональным прочессам регулирования финансовых секторов экономики, которые в последние годы становятся приоритетными, требует от научной среды выявления общих признаков финансовых кризисов, идентичности отдельных их проиессов, выявление и классификацию реперных точек, воздействие на которые даст максимальный эффект от разработки и внедрения 
антикризисных мер. Кроме того, приобретает актуальность вопрос разработки и унификации методов и моделей проведения стресс-тестирования.

Важным моментом для повышения эффективности проиесса стресс-тестирования является понимание его сущности, ичели проведения и задач, которые будут решены в процессе стресстестирования банков.

Проведенное в работе исследование позволяет утверждать, что стресс-тестирование - это проиесс количественной оченки риска, который заключается в определении величины несогласованной позичии, которая подвергает банк риску, и в определении количественных показателей внешних факторов влияния, которые показывают, какую сумму убытков получит банк, если события будут развиваться по заложенными негативными сценариями, разработке мероприятий по установлению количественных показателей деятельности отдельного банка или банковской системы страны в целом, обеспечивающих создание соответствующих условий деятельности, при которых банк или банковская система в целом сможет предотвратить влияние негативных явлений вообще, или максимально минимизировать их влияние.

Целью проведения стресс-тестирования является достижение отдельным банком, или банковской системой в иелом такого состояния, при котором будет обеспечена максимально возможная минимизация влияния негативных событий на микро - и макроуровне, которые имеют маловероятен характер, однако могут привести к кризисным ситуациям.

Ключевые слова: риск-менеджмент, стресс-тестирование, банковские риски, методы стресстестирования, ичель стресс-тестирования.

Yu.M. BEZDITKO Kherson National Technical University O.M. POSADNEVA Kherson National Technical University M.V. KAGARLITSKA Kherson National Technical University

\section{THEORETICAL ASPECTS OF THE STRESS TESTING APPLICATION IN THE BANKING SYSTEM OF UKRAINE}

In the context of globalization of the world economy, quantitative and qualitative characteristics of risks are growing, which encourages banks to develop and implement in everyday activities mechanisms that not only minimize risks, but also their forecasting, which ultimately will only reduce the negative impact of risks on financial-economic activities of banks, and in the best case in general to prevent their occurrence. One such tool, which has become popular and relevant in recent decades, has been stress testing.

The transition to prudential processes of regulation of financial sectors of the economy, which in recent years have become a priority, requires the scientific community to find out common signs of financial crises, the identity of their individual processes, identify and classify defining points, the impact of which will maximize the development and implementation of crisis measures. In addition, the issue of developing and unifying methods and models of stress testing is becoming relevant.

An important point to increase the efficiency of the stress testing process is to understand its essence, purpose, and tasks that will be solved in the process of stress testing of banks.

The study suggests that stress testing is a process of quantitative risk assessment, which consists in determining the amount of uncoordinated position that exposes the bank to risk, and in determining the quantitative indicators of external factors that show how much damage the bank will receiv, if events develop according to the set negative scenarios, development of measures to establish quantitative indicators of individual bank or banking system of the country as a whole, which will ensure the creation of appropriate conditions under which the bank or banking system as a whole can prevent negative effects in general or minimize their influence.

The purpose of stress testing is for an individual bank or the banking system as a whole to achieve a state that will minimize the impact of adverse events at the micro and macro levels, which are unlikely, but can lead to crises.

Key words: risk management, stress testing, banking risks, stress testing methods, purpose of stress testing.

\section{Постановка проблеми}

Ризик є невід'ємним атрибутом функціонування всякої фінансової установи, а особливо банків, основним видом діяльності яких $є$ надання коштів, при цьому не власних, а залучених та запозичених, в борг, тобто в кредит. Відповідно специфічною особливістю діяльність банків на ринку фінансових послуг $\epsilon$ перманентне вирішенням протиріччя - отримання прибутку при певному, допустимому рівні 
ризику. При цьому значне розмаїття різних видів ризиків приводить до того, що досягти нульового їх рівня неможливо. Таким чином, одним із наріжних каменів діяльності банку є максимально можлива мінімізація ризиків його діяльності.

В умовах глобалізації світової економіки, кількісні та якісні характеристики ризиків зростають, що спонукає банки до розробки та впровадження в повсякденну діяльність механізмів які не тільки забезпечують мінімізацію ризиків, а і їх прогнозування, яке дасть можливість банкам розробляти та вдосконалювати інструменти зменшення ризиків як на мікро- так і макрорівні, які в кінцевому порядку дадуть можливість на тільки мінімізувати негативний вплив ризиків на фінансово-господарську діяльність банків, а у самому оптимальному варіанті взагалі запобігти їх виникненню.

Одним із таких інструментів, який став популярним та набув своєї актуальності в останні десятиліття, стало стрес-тестування. Необхідно зауважити, що процес мінімізації ризиків при проведенні кредитних операцій має довге, історичне підгрунтя, однак значна кількість фінансових криз, які почали інтенсивно виникати починаючи з 90-х років XX ст., примусили науковців та практиків, які проводять свою діяльність у фінансових секторах економіки, розширити кількісно та поглибити якісно дослідження, які стосуються механізмів стрес-тестування.

Міжнародний валютний фонд (МВФ), Світовий банк, Банк міжнародних розрахунків спільно 3 національними регуляторами і фінансово-кредитними інститутами різних країн посилили роботу 3 вдосконалення проведення стрес-тестування. Спочатку стрес-тести застосовувались як інструменти оцінки ризиків на рівні окремих портфелів різного виду фінансово-кредитних установ, однак в останні роки воно набуло значної популярності. Необхідність застосування фінансово-кредитними установами і в першу чергу банками механізму стрес-тестування зафіксована в Міжнародній угоді вимірювання капіталу і стандартів капіталу (Базель II). В основних принципах ефективного банківського нагляду (Принцип №7 «Процес ризик менеджменту») відмічається, що банки зобов'язані проводити стрестестування, орієнтоване на перспективу, в якому будуть виявлятися потенційні події або зміни в ринкових умовах, що мають негативний вплив на банк.

Національним банком України розроблено методичні рекомендації, які стосуються застосування стрес-тестування в банках, проте аналіз сучасних наукових публікацій показує, що стрес-тести, які ефективний інструмент виявлення та попередження ризиків у банківських установах потребує подальшого дослідження та вдосконалення методологічних та методичних засад.

Аналіз останніх досліджень і публікацій

Аналіз останніх досліджень і публікацій дозволяє зробити висновок про значну зацікавленість проблемами стрес-тестування як вітчизняними, так і закордонними науковцями. Зокрема розробці теоретичних засад стрес-тестування приділяли увагу Т.Л. Мостенська, Н.С. Скопенко, Ф. Банн, П. П. Ковальов, І. В. Пашковська, С. Самолов, А. М. Тавасієв та ін.

\section{Формулювання мети дослідження}

Метою даного наукового дослідження є поглиблення теоретичних і практичних напрацювань щодо використанні стрес-тестування як одного із інструментів ризик-менеджменту банків.

\section{Викладення основного матеріалу дослідження}

Як свідчить світовий досвід, стрес-тестування не є новим інструментом в системі банківського ризик-менеджменту, однак в останній час, внаслідок збільшення кількості кризових явищ як у сфері фінансів і банківської діяльності, так і інших сферах, які прямо, або дотично впливають на безпеку функціонування банківських систем, його роль істотно зросла. Наочним прикладом нестабільності банківських систем може виступати динаміка кількості банків в Україні (Табл. 1).

Динаміка кількості банків в Україні за 2015-2019 роки наочно показує, що банківська система України поки що є нестабільною, особливо що стосується банків 3 національним приватним капіталом, $\mathrm{i}$ ризики ведення банківського бізнесу є дуже високими.

Таблиця 1

Показники кількості банків , в тому числі з іноземним капіталом в Україні за 2015-2019 роки, одиниць*

\begin{tabular}{|l|c|c|c|c|c|}
\hline \multicolumn{1}{|c|}{ Показник } & \multicolumn{5}{|c|}{ Роки } \\
\cline { 2 - 6 } & 2015 & 2016 & 2017 & 2018 & 77 \\
\hline $\begin{array}{l}\text { Кількість діючих } \\
\text { банків }\end{array}$ & 117 & 96 & 82 & 37 & 35 \\
\hline $\begin{array}{l}\text { 3 них: з іноземним } \\
\text { капіталом }\end{array}$ & 41 & 38 & 18 & 23 & 23 \\
\hline $\begin{array}{l}\text { у т.ч. зі } 100 \% \\
\text { іноземним капіталом }\end{array}$ & 17 & 17 & 18 & 75 \\
\hline
\end{tabular}

*Примітка. Складено автором за даними [1]. 
Враховуючи ефективність та важливість використання стрес-тестування як інструменту мінімізації впливу ризиків перманентно присутніх у діяльності всіх кредитно-фінансових установ, які професійно займаються наданням коштів у борг, в першу чергу банків, розробці та вдосконаленню механізму стрес-тестування приділяється значна увага, як національними регуляторами ринку банківських послуг, так і міжнародними. Так у 1990 році, з метою встановлення кількісних показників вимірювання ризиків функціонування національних фінансових систем, Міжнародним валютним фондом та Світовим банком запроваджено програму оцінки фінансового сектора FSAP (Financial Sector Assessment Program), в рамках якої було розроблено перші стрес-тести з використанням макроекономічних моделей, які охоплювали кредитний, процентний, ринковий, операційний ризики та ризик ліквідності [11]. В подальшому запропоновані моделі використовувалися для стану банківських систем Великобританії, Данії, Австрії, Чехії, Угорщини, Канади та інших країн.

Вперше стрес-тестування банківської системи на основі запропонованих моделей на системній основі було впроваджено в США. Згодом і країни Євросоюзу підключилися до цього процесу, зокрема стрес-тестування в $€ C$ проводиться за дорученням Ради міністрів $€ \mathrm{C}$ з питань економіки й фінансів $\mathrm{i}$ координується Європейським комітетом органів банківського нагляду разом 3 Європейським центральним банком, а також за участю національних наглядових органів і Європейської Комісії [12]. У 1998 році і Базельський комітет з банківського нагляду акцентував увагу на необхідності проведення стрес-тестування в банках. Так у другій Базельській угоді (Базель II) запропоновано проведення стрестестування не лише ринкового ризику, але й інших видів ризику, в тому числі кредитного. Зокрема базельський комітет з банківського нагляду запропонував тлумачення кредитного ризику як вірогідну оцінку чутливості портфелів (кредитного, цінних паперів, дебіторської заборгованості та позабалансових кредитних зобов'язань) банку залежно від дії різних екстремальних подій, що розглядаються як виключні, але гіпотетично можливі [12]. Починаючи з 1999 року механізми стрес-тестування почали широко застосовуватися Міжнародним валютним фондом та Світовим банком для оцінки уразливості банківських систем до світових фінансових криз.

Дослідження досвіду світових фінансових криз свідчить, що спектр причин їх виникнення, процесів перебігу, наслідків, за своєю глибиною та розмаїттям відтінків надзвичайно різноманітний. Однак перехід до пруденційних процесів регулювання фінансових секторів економіки, які в останні роки стають пріоритетними, вимагає від наукового середовища виявлення спільних ознак фінансових криз, ідентичності окремих їх процесів, виявлення та класифікацію реперних точок, вплив на які дасть максимальний ефект від розробки та впровадження антикризових заходів. Крім того набуває актуальності питання розробки та уніфікації методів та моделей проведення стрес-тестування.

Важливим моментом для підвищення ефективності процесу стрес-тестування $є$ розуміння його сутності, мети проведення, та завдань, які будуть вирішені в процесі стрес-тестування банків. Для визначення сутності стрес-тестування як одного із інструментів ризик-менеджменту, на нашу думку спочатку необхідно визначити мету яка повинна бути досягнута в процесі проведення стрес-тестування, та задачі які будуть вирішені в процесі проведення стрес-тестування, тобто використаємо метод «від зворотного».

Якщо розглядати стрес-тестування як один із інструментів ризик-менеджменту, який по суті $є$ сукупністю принципів, методів і форм управління організацією та іiі поведінкою в зовнішньому середовищі в умовах невизначеності та конфліктності, метою якого $є$ зменшення або ліквідація можливих втрат від ризику [2], то і стрес-тестування необхідно розглядати як складову саме цього процесу.

Незважаючи на те, що ризик-менеджмент як процес мінімізації ризиків може бути використаний всіма суб'єктами економічних відносин незалежно від сфери та виду їх діяльності, на сьогоднішній день механізм стрес-тестування розглядається як інструмент мінімізації ризиків саме у банківській сфері, i всі методології та методики спрямовані саме на цей сектор економіки.

Відповідно до методичних рекомендацій щодо порядку проведення стрес-тестування в банках України, схвалених Постановою Правління Національного банку України від 06.08.2009 № 460, метою проведення стрес-тестування $є$ оцінка ризиків та визначення спроможності протистояти потрясінням на фінансовому ринку.

Вважається, що за допомогою стрес-тестування банк може визначити розмір збитків у цілому та за окремими видами активів у разі виникнення екстремальних подій, а також свої потенційні можливості покривати ці збитки, оцінити стан власного капіталу та визначити якість власних методик щодо управління ризиками.

Відповідно, основним завданням стрес-тестування в цих методичних рекомендаціях $\epsilon$ підготовка упереджувальних стратегічних і тактичних заходів, які дозволять врегулювати проблемні або напружені ситуації, що можуть виникнути в майбутньому, та послабити вплив різних ризиків на діяльність банків [3]. 
Тарасевич Н.В. та Литвиненко А.М. метою стрес-тестування визначають оцінку можливих збитків банківської системи при настанні певних подій. В результаті аналізу виходить якась інтегральна оцінка, що дозволяє визначити, при зміні яких умов (факторів) банк опиниться в критичному стані. Таким чином, розписується сценарій стану банку в стресі.

Необхідність стрес - тестування вони вбачають в тому, що вже на ранніх етапах можна спрогнозувати зміни в системі і сформувати попереджуючі заходи для недопущення стресу або (при настанні стресу) мати уявлення про те, як зреагує на це система

3 їх точки зору за допомогою стрес-тестування банк може виконати наступні завдання:

банку;

- ідентифікувати ключові фактори ризику та загрози для фінансової та економічної безпеки

- визначити розмір збитків в цілому i по окремих видах активів у разі виникнення екстремальних подій, а також свої потенційні можливості покрити ці збитки;

- оцінити стан власного капіталу і визначити якість власних методик з управління ризиками;

- оцінити адекватність процесів управління проблемними активами та визначити достатність резервів для відшкодування можливих втрат;

- визначити рівень фінансової стійкості банку;

- розробити систему заходів для підтримки належного рівня безпеки банківської діяльності та фінансової стабільності, зниження рівня ризику, нейтралізації загроз і мінімізації можливих негативних наслідків [4].

Дульська В.I. метою проведення стрес-тестування визначає оцінку вразливості портфелів фінансових інструментів або банку в цілому до значних негативних змін макроекономічного характеру та «екстремальних» подій, які мають малоймовірний характер, проте можуть призвести до кризових ситуацій, які важко піддаються прогнозуванню та здатні призвести до аномально великих збитків.

Вона вважає, що основними завданнями «стрес-тестування»є можливість:

- оцінити потенційний вплив на фінансовий стан банку певних змін в ризик-факторах (оцінити чутливість до ризиків), i, як наслідок, градацію факторів ризику за рівнем можливих втрат;

- оцінити, чи здатний капітал банку компенсувати можливі непередбачені втрати, які можуть бути понесені банком на випадок реалізації умов стрес-тестування;

- провести підготовчі заходи на випадок стресового сценарію, розробити процедури зменшення потенційних втрат;

- оцінити рівень змін ризик-факторів, за яких наступає дефолт банку;

- оцінити вплив на капітал банку результатів стрес-тестування [5].

У приведених тлумаченнях мети проведення стрес-тестування визначено, по-перше, що це процес, а по-друге, який забезпечує проведення оцінки - «оцінки ризиків», «оцінки можливих збитків», «оцінки вразливості портфелів». Однак якщо виходити з того, що: «Мета (від лат. теtа) означає стан в майбутньому, який можливо змінити відносно теперішнього та варто, бажано або необхідно досягнути. У такий спосіб мета $€$ бажаною кінцевою точкою процесу ... .», то виходить, що в приведених тлумаченнях мети кінцевою метою стрес-тестування є тільки оцінка. Звичайно, процес оцінки теж може бути поставлений в якості мети, однак у нашому випадку процес проведення стрес-тестування не може бути поставлений в якості мети, оскільки це буде проміжний результат. Кінцевим результатом стрестестування, на нашу думку, повинен стати такий стан окремого банку, чи банківської системи країни в цілому, при якому буде забезпечено створення відповідних умов діяльності, за яких банк зможе запобігти впливу негативних явищ взагалі, або максимально мінімізувати їх вплив.

Тому ми вважаємо, що метою проведення стрес-тестування є досягнення окремим банком, чи банківською системою в цілому такого стану, при якому буде забезпечено максимально можливу мінімізацію впливу негативних подій на мікро - та макрорівні, які мають малоймовірний характер, проте можуть призвести до кризових ситуацій.

Відповідно до визначеної мети, можна визначити завдання, які необхідно вирішити в процесі стрес-тестування. На нашу думку, у вище приведених переліках завдань в сукупності, охоплено весь необхідний спектр завдань, які повинен вирішити банк в процесі, і за результатами стрес-тестування. 3 нашої точки зору їх умовно можна поділити на три блоки з певною послідовністю блоків (Рис. 1).

Звичайно, перелік завдань, які повинен реалізувати банк може і повинен бути розширений, можливо змінений, в залежності від виду та негативної глибини кризової ситуації, а також фінансового та економічного стану банку на початку кризи.

Оцінюючи приведені тлумачення мети та завдань стрес-тестування, проведемо оцінку існуючих дефініцій стрес-тестування, та сформулюємо власне бачення його сутності. Аналіз та оцінка існуючих дефініцій стрес-тестування дає можливість виокремити два основні напрями у визначення сутності стрес-тестування.

Як правило у методичних рекомендаціях державних та наддержавних регуляторів банківського ринку, зокрема Міжнародного валютного фонду, Банку міжнародних розрахунків [6], Національного 
банку України [3] а також окремих науковців - Щербатих Д.В. [7], професор А.М. Тавасіев [8] стрестестування визначається як певний набір методів спрямованих на визначенні та оцінці можливих негативних явищ. Зокрема у всіх приведених тлумаченнях стрес-тестування, його сутність визначається як метод - спосіб досягнення поставленої мети, або поєднання методів, тобто поєднання методів, оцінки ризиків або певних змін у діяльності банків. Відповідно, стрес-тестування представлене статичним явищем, яке передбачає спосіб, або поєднання способів досягнення поставленої мети, хоча подальша оцінка приведених дефініцій стрес-тестування показує що методи або група методів все ж таки спрямовані на проведення оцінки ризиків, стану, уразливості тощо.

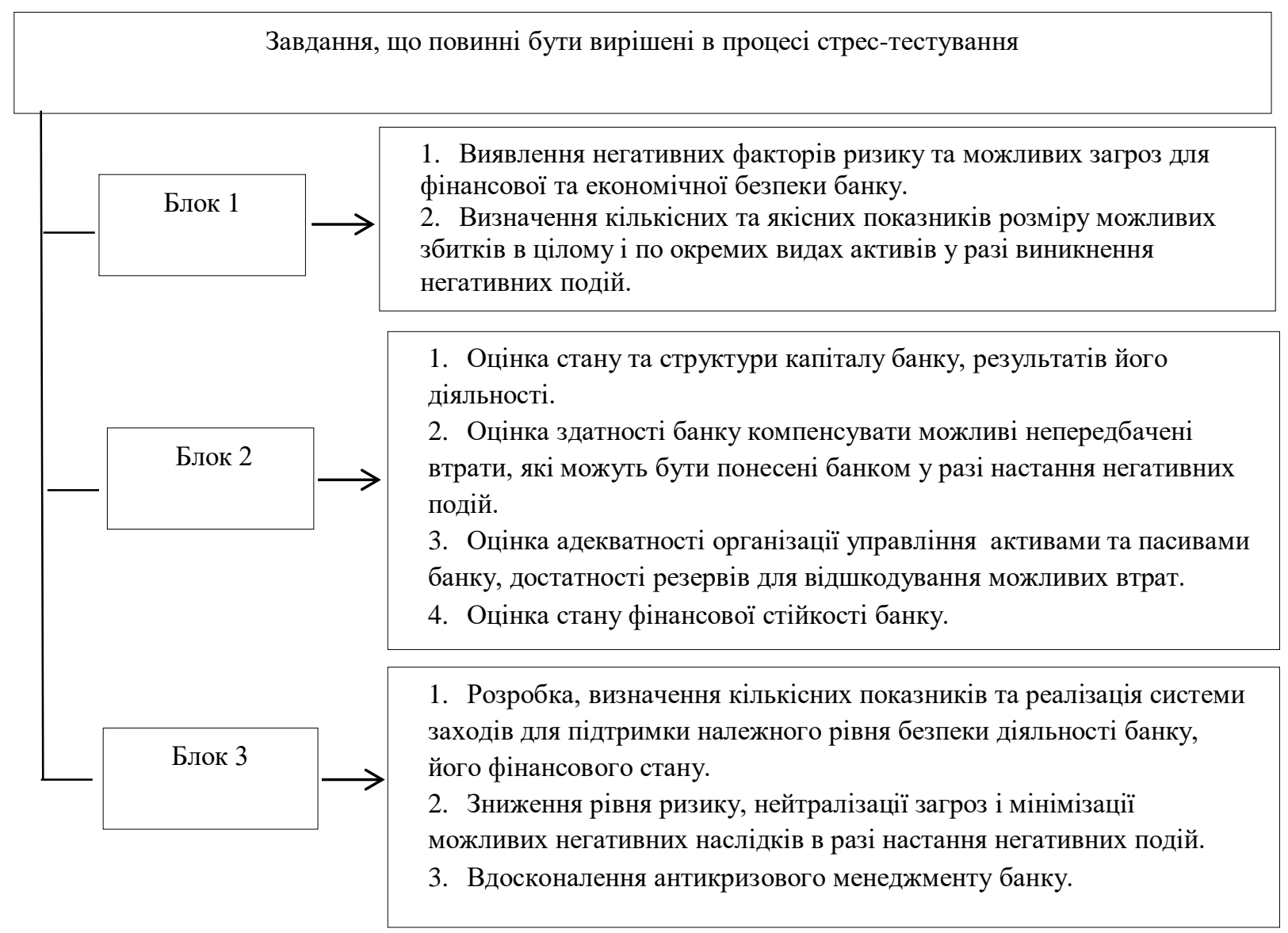

Рис.1. Перелік завдань, які повинні бути вирішені в процесі проведення стрес-тестування. [Складено автором за даними 4, 5, 6]

Тому на нашу думку стрес-тестування слід тлумачити як процес проведення оцінки негативних явищ, які шкідливо впливають на діяльність банків. Таке тлумачення приводиться у нормативних документах Центрального банку Росії [9], у працях Ліндер Є. [10], Тарасевич Н.В., Литвиненко А.М. [4].

В приведених дефініціях, стрес-тестування тлумачиться як процес перевірки, чи процес оцінки різних негативних явищ, пов'язаних з діяльністю або окремого банку, або банківської системи в цілому. Такий підхід, на нашу думку, є більш правильним при визначенні сутності стрес-тестування.

Крім того, у приведених в дослідженні, та інших тлумаченнях сутності стрес-тестування, кінцевою метою його проведення визначається оцінка можливих збитків або негативного ефекту від ймовірних подій. Однак, як ми визначали раніше, процес визначення, та навіть кількісна оцінка можливих негативних наслідків від настання певних подій, не може бути кінцевою метою стрестестування банку, оскільки метою (за визначенням) є досягнення в майбутньому стану, який забезпечить досягнення окремим банком, чи банківською системою в цілому таких показників фінансовоекономічного стану банку, та відповідного рівня менеджменту, при якому буде забезпечено максимально можливу мінімізацію впливу негативних подій на мікро- та макрорівні, які мають малоймовірний характер, проте можуть призвести до кризових ситуацій. Досягнення таких показників можливе лише завдяки розробці та виконанню заходів приведених нами у третьому блоці завдань, які забезпечать досягнення мети в процесі проведення стрес-тестування.

Підводячи підсумок проведеному дослідженню, можна сформулювати власне бачення сутності стрес-тестування - це процес кількісної оцінки ризику, який полягає у визначенні величини неузгодженої 
позиції, яка наражає банк на ризик, та у визначенні кількісних показників зовнішніх чинників вплив, які показують, яку суму збитків отримає банк, якщо події розвиватимуться за закладеними негативними сценаріями, розробці заходів по встановленню кількісних показників діяльності окремого банку чи банківської системи країни в цілому, що забезпечать створення відповідних умов діяльності, за яких банк чи банківська система в цілому зможе запобігти впливу негативних явищ взагалі, або максимально мінімізувати їх вплив.

\section{Висновки}

Проведене в роботі дослідження дає змогу зробити наступні висновки.

1. Стрес-тестування як ефективний інструмент мінімізації ризиків в діяльності як банків, так i небанківських кредитно-фінансових установ, вперше був запропонований до використання міжнародними кредитно-фінансовими установами - Міжнародним валютним фондом та Світовим банком у 1990 році, з метою встановлення кількісних показників вимірювання ризиків функціонування національних фінансових систем.

2. Дослідження теоретичних засад стрес-тестування дає підстави стверджувати, що стрестестування - це процес кількісної оцінки ризиків, який полягає у визначенні величини неузгодженої позиції, яка наражає банк на ризик, та у визначенні кількісних показників зовнішніх чинників впливу, які показують, яку суму збитків отримає банк, якщо події розвиватимуться за закладеними негативними сценаріями, розробці заходів по встановленню кількісних показників діяльності окремого банку, чи банківської системи країни в цілому, що забезпечать створення відповідних умов діяльності, за яких банк чи банківська система в цілому зможе запобігти впливу негативних явищ взагалі, або максимально мінімізувати їх вплив.

3. На сьогоднішній день як в Україні, так і у світі, продовжується процес вдосконалення механізму стрес-тестування, оскільки поки що відсутні єдині деталізовані методики та алгоритми проведення стрес-тестування в банках, які б охоплювали максимально можливий спектр можливих ризиків притаманних діяльності банків, та могли б застосовуватись як до окремих банків чи їх груп, так i до банківської системи України в цілому.

\section{Список використаної літератури}

1. Грошово-кредитна статистика. Офіційний сайт Національного банку України. URL: http://www.bank.gov.ua/control/uk/publish/category?cat_id=44579.

2. Мостенська Т. Л., Скопенко Н. С. Ризик-менеджмент як інструмент управління господарським ризиком підприємства. Вісник Запорізького національного університету. 2010. № 3(7). С. 73-79

3. Методичні рекомендації щодо порядку проведення стрес-тестування в банках України. Постанова Правління Національного банку України від 06.08.2009 № 460. URL: https://zakon.rada.gov.ua/laws/show/v0460500-09\#Text

4. Тарасевич Н. В., Литвиненко А. М. Стрес-тестування ризиків як інструмент антикризового управління діяльністю банків. Финансы, учет, банки. 2014. № 1 (20). С. 255-163

5. Дульська В. І. Методичні підходи до проведення стрес-тестування банків як інструменту аудиту. Сталий розвиток економіки. 2013. № 2. С. 251-253. URL: http://nbuv.gov.ua/UJRN/sre_2013_2_54

6. Андриевская И. Стресс-тестирование: обзор методологий. Управление в кредитной организации. 2007. № 5. С. 88 - 96

7. Щербатих Д. В. Сучасні методи стрес-тестування банківської системи України. Мукачівський державний університет. Економіка і суспільство. Випуск 19 / 2018. С. 1210-1218

8. Тавасиев А. М. Антикризисное управление кредитными организациями. Учебное пособие. Москва: Издательство «ЮНИТИ-ДАНА

9. Подходы к организации стресс-тестирования в кредитных организациях (на основе обзора международной финансовой практики). Центральный банк Российской Федерации, 2003. URL : http://www.cbr.ru/analytics/bank_system/print.asp?file=stress.htm.

10. Ліндер С. Стрес-тестування як інструмент аналізу фінансової стійкості банківських установ. Інститут бухгалтерського обліку, контроль та аналіз в умовах глобалізації. Міжнародний науковий журнал. 2016. Випуск 4. С. 73-79

11.Бєленька Г. Стрес-тестування як метод оцінки стабільності банківської системи: етапи, методологія та світовий досвід. Вісник СНАУ. 2008. № 2. С. 187 - 193.

12. Житний П. Є., Шаповалова С. М., Карамишева Г. М. Світова практика стрес-тестування у банках України. Вісник Української академії банківської справи. 2011. № 1(30). С. 67 - 72. 
1. Groshovo-kredy'tna staty`sty`ka. Oficijny`j sajt Nacional’nogo banku Ukrayiny`. URL: http://www.bank.gov.ua/control/uk/publish/category?cat_id=44579.

2. Mostens`ka T. L., Skopenko N. S. Ry`zy`k-menedzhment yak instrument upravlinnya gospodars`ky’m ry`zy`kom pidpry`yemstva. Visny`k Zaporiz`kogo nacional’nogo universy`tetu. 2010. No. 3(7). pp. 73-79

3. Metody`chni rekomendaciyi shhodo poryadku provedennya stres-testuvannya $\mathrm{v}$ bankax Ukrayiny`. Postanova Pravlinnya Nacional'nogo banku Ukrayiny vid 06.08.2009 no. 460. URL: https://zakon.rada.gov.ua/laws/show/v0460500-09\#Text

4. Tarasevy`ch N. V., Ly`tvy`nenko A. M. Stres-testuvannya ry`zy'kiv yak instrument anty' kry`zovogo upravlinnya diyal'nistyu bankiv. Fy’nansu, uchet, banky'. 2014. no. 1 (20). pp. 255-163

5. Dul's`ka V. I. Metody`chni pidxody' do provedennya stres-testuvannya bankiv yak instrumentu audy`tu. Staly j rozvy`tok ekonomiky`. 2013. no. 2. pp. 251-253. URL: http://nbuv.gov.ua/UJRN/sre_2013_2_54

6. Andry`evskaya $Y^{\prime}$. Stress-testy`rovany`e: obzor metodology`j. Upravleny`e v kredy`tnoj organy`zacy`y`. 2007. no. 5. pp. $88-96$

7. Shherbaty`x D. V. Suchasni metody` stres-testuvannya bankivs`koyi sy`stemy` Ukrayiny`. Mukachivs`ky`j derzhavny’j universy`tet. Ekonomika i suspil`stvo. Vy`pusk 19 / 2018. pp. 1210-1218

8. Tavasy'ev A. M. Anty'kry`zy'snoe upravleny'e kredy'tnыmy' organy'zacy'yamy'. Uchebnoe posoby`e. Moskva: Y`zdatel`stvo 《'YuNY`TY`-DANA», 2010.

9. Podxodы k organy'zacy'y' stress-testy'rovany'ya $\mathrm{v}$ kredy`tnux organy`zacy'yax (na osnove obzora mezhdunarodnoj fy'nansovoj prakty'ky'). Central'nuj bank Rossy'jskoj Federacy'y', 2003. URL : http://www.cbr.ru/analytics/bank_system/print.asp?file=stress.htm.

10. Linder Ye. Stres-testuvannya yak instrument analizu finansovoyi stijkosti bankivs`ky`x ustanov. Insty`tut buxgalters`kogo obliku, kontrol` ta analiz v umovax globalizaciyi. Mizhnarodny`j naukovy`j zhurnal. 2016. Vỳ pusk 4. pp. 73-79

11. Byelen`ka G. Stres-testuvannya yak metod ocinky` stabil`nosti bankivs`koyi sy`stemy`: etapy`, metodologiya ta svitovy`j dosvid. Visny`k SNAU. 2008. N0. 2. pp. 187 - 193.

12. Zhy`tny`j P. Ye., Shapovalova S. M., Karamy`sheva G. M. Svitova prakty`ka stres-testuvannya u bankax Ukrayiny`. Visny`k Ukrayins`koyi akademiyi bankivs`koyi spravy`. 2011. no. 1(30). pp. 67 - 72. 